\title{
ASPECTE PSIHOLOGICE ŞI ETICE LEGATE DE PREZENȚA MEMBRILOR FAMILIEI ÎN TIMPUL RESUSCITĂRII CARDIACE LA COPIL
}

\author{
Magdalena Iorga ${ }^{1}$, Georgiana Russu ${ }^{2}$, Florin D. Petrariu ${ }^{\mathbf{1}}$ \\ ${ }^{1}$ Ştiințele comportamentului, Departamentul de Medicină Preventivă şi \\ Interdisciplinaritate, Universitatea de Medicină şi Farmacie „, Gr. T. Popa “, Iaşi \\ ${ }^{2}$ Secția de Cardiologie Pediatrică, Spitalul de Urgență pentru Copii ,,Sfânta Maria“, Iaşi
}

\begin{abstract}
REZUMAT
Prezența membrilor familiei pe parcursul investigațiilor medicale a determinat dezbateri intense. Aceste dispute au avut în centrul lor atât aspectele etice, psihologice, cât şi politice. Autorii abordează teoretic aspecte legate de prezența familiei pe parcursul interventiiilor medicale în cazul copiilor cu probleme cardiace, în special al manevrelor de resuscitare. În acest domeniu s-au acumulat argumente şi contra-argumente generate de politicile de sănătate din diverse tări, nivelul de colaborare al familiei, pregătirea specială a medicilor şi a întregii echipe implicată în resuscitare, includerea participării familiei în protocoalele de lucru şi crearea condițiilor pentru desfăşurarea resuscitării în această modalitate.

Cuvinte cheie: copil, deficiențe cardiace, malformații, resuscitare, familie, distres psihologic, terapie
\end{abstract}

\section{INTRODUCERE}

Prezența membrilor familiei pe parcursul investigațiilor medicale este un subiect care a fost intens dezbătut şi pentru care au fost lansate opinii pro şi contra. Ele s-au referit la părerea opiniei publice, pacienți, familiile acestora, cât şi a personalului medical şi cercetătorilor. Direcțiile de cercetare ale acestei problematici s-au orientat atât către aspectele etice (legate de autonomia pacientului, dreptul de a i se construi întreg contextul bio-psiho-medical pentru a-şi recâştiga sănătatea, dreptul familiei de a se implica în recuperarea pacientului), psihologice (reducerea nivelului de distres psiho-fizic al pacientului prin prezența unei persoane apropiate, dar şi al familiei prin înțelegerea adecvată a situației), cât şi politice (reducerea problemele litigioase prin eliminarea îndoielii familiei cu privire la eforturile depuse de personalul medical sau a deciziilor luate în situații dificile).

În spitalele de pediatrie, includerea membrilor familiei în echipa multidisciplinară care îngrijeşte copilul a câştigat teren în multe țări şi a devenit un marker al calității serviciilor oferite copiilor, mai ales în unităţile de urgență (1). Crearea spațiilor special destinate părinților, amenajarea unor încăperi pentru odihna acestora şi acceptarea lor pe parcursul manevrelor medicale au fost criterii impuse de către decidenții politicilor de sănătate din întreaga lume.

Trebuie menționat că nu toate țările din Europa agreează prezența părinţilor sau membrilor familiei pe parcursul manevrelor de resuscitare. Printre cauzele principale menționăm modelul hiperprotector de îngrijire sau contextul cultural şi religios. Integrarea aspectelor care țin de cultură şi religie sunt încurajate în unele țări şi se referă atât la consilierea spirituală a pacienților şi a familiilor, cât şi la respectarea obiceiurilor din timpul desfăşurării momentelor critice (rugăciunea, incantațiile, versetele sau ritualurile). Astfel este facilitată integrarea momentului critic în desfăşurarea evenimentelor din viaţa de familie şi depăşirea momentului morții cu mai puține consecințe de ordin psiho-emoțional. Credinţele cu privire la momentele dificile şi la moarte sunt puternic influenţate cultural şi ele pot urmări martorul la evenimentul critic, pe tot parcursul vieții. Din acest motiv, integrarea membrilor 
familiei pe parcursul manevrelor de resuscitare trebuie să fie rezultatul unui bun proces de management al situatiei în care protocolul spitalului, temerile personalului medical și dorintele membrilor familiei şi ale pacientului trebuie să se îmbine armonios, în beneficiul tuturor.

\section{Prezența familiei pe parcursul CPR - între argumente şi contra-argumente}

\section{Perspectiva politicilor de sănătate}

Participarea membrilor familiei la manevrele de resuscitare cardio-pulmonară este propusă încă din 1987, fiind un concept relativ nou în îngrijirea pacientului. În anul 2010, American Heart Association a transformat propunerea în recomandare a prezenței membrilor familiei pe parcursul CPR, dar fără suficiente dovezi statistice privind beneficiile sau consecințele negative ale acestei măsuri (2).

$\mathrm{O}$ poziție comună cu privire la participarea membrilor familiei la resuscitarea cardio-pulmonară a pacienților a fost formulată în comun şi ratificată de către European federation of Critical Care Nursing associations (EfCCNa, ratificată în data de 28 aprilie 2007), European Society of Paediatric and Neonatal Intensive Care (ESPNIC, ratificată în 10 februarie 2007), European Society of Cardiology Council on Cardiovascular Nursing and Allied Professions (CCNAP, în 16 iunie 2007) şi publicată în European Journal of Cardiovascular Nursing (3).

În anul 2012, Academia Americană de Pediatrie a dat o nouă direcției serviciilor medicale asigurate copiilor, recomandând orientarea către îngrijirea centrată pe pacient, dar şi familie. Această directivă propusă ca politică de sănătate aduce în prim-plan consecințele pozitive ale îngrijirii copiilor în aceste condiții. Este accentuată importanța implicării membrilor familiei, copilului şi tânărului adult în procesul luării deciziilor care privesc calitatea vieții şi bunăstarea bio-psiho-socială a pacientului şi familiei acestuia. Sunt propuse recomandări specifice pediatrilor pentru a integra terapia centrată pe pacient şi familie în cadrul practicii medicale în spitale, clinci şi centre de îngrijire comunitare (4). Recomandările AAP se referă la acceptarea părinților ca parteneri în îngrijirea pacientului indiferent de rasă, etnie, cultură, situație socio-economică şi recomandă acordarea sprijinului formal și informal membrilor familiei, respectând cadrul etico-legal.

Studiile realizate în spitalele de pediatrie din SUA dovedesc faptul că deschiderea către sistemul de îngrijire orientat către familie şi pacient a adus beneficii financiare spitalelor. Participarea părinților la spitalizarea şi tratamentul copiilor a determinat creşterea gradului de satisfacție al părinților, diminuarea numărului de zile de spitalizare a copiilor precum şi reducerea frecvenței apelurilor la ajutorul serviciilor de urgență. (5) Costurile asociate spitalizărilor şi reducerea evenimentelor litigioase au avut ca şi consecință reducerea investițiilor pe aceste direcții şi orientarea lor către cele în beneficiul pacienților şi a familiilor lor (tratamente, spații de locuit pentru părinții însoțitori, servicii medicale etc).

\section{Perspectiva pacientului}

Îngrijirea pacientului, atât la domiciliu cât şi acasă, precum şi acordarea intervenției de urgență în cazul situațiilor critice, reprezintă un proces cu încărcătură psihoeomoțională mare, la care pacientul, în special pediatric, are nevoie de sprijin din partea celor apropiați. Nivelul distresului fizic şi psihic provocat de evenimentul în sine poate fi ameliorat de prezența rudelor. Familia este o sursă unică prin care informații cu privire la personalitatea, comportamentul, aşteptările, credințele şi imaginea despre boală a micului pacient pot fi făcute cunoscute personalului medical.

Chiar dacă deciziile aparțin medicului, ele sunt luate în acord cu familia şi comunicate pacientului într-o modalitate prin care acestea să fie cât mai corect înțelese şi asimilate. Complianța depinde şi de modalitatea în care părinții participă, pentru că informațiile oferite de aceştia cu privire la profilul psihologic şi comportamentul copiilor sunt un factor important în stabilirea strategiilor de intervenție.

Restricțiile anterioare impuse accesului membrilor familiei în clinici a determinat ca ruperea copilului de mediul familial (părinți, frați, alte rude) şi de şcoală să fie un factor important al creşterii nivelului de distres, mai ales în clinicile cu intervenții de urgență. Aici succesiunea evenimentelor este rapidă inducând familiei impresia că nu ține pasul cu etapele interventiiilor, că bolnavul este lipsit de un mediu cât mai apropiat de cel obişnuit (6). Dar pacientul şi familia trebuie să înțeleagă că unele restricții sunt determinate de interesul pentru sănătatea post-intervenție a pacientului, în sensul ca acesta trebuie ferit de factori suplimentari de distres fizic şi psihic precum infecții, starea emoțională a rudelor care îl vizitează etc. Efectul pozitiv al suportului familial este dovedit prin numeroase cercetări.

Momentele de reticență ale personalului medical trebuie justificate (prezentate şi explicate) familiei. Prezentarea pas cu pas a situației bolnavului va determina aşteptări conforme cu etapele următoare, iar participarea părintelui asigură bolnavului un nivel de încredere mai mare, diminuând angoasa şi 
suspiciunea. Pacientul nu va fi văzut ca un obiect, ci ca o persoană care este dependentă şi integrată între membrii familiei.

Din punct de vedere psihologic, teoria ataşamentului a lui Bowlby (7) poate explica motivele pentru care a fost necesară impunerea acestei modificări. Studiile realizate pe copiii spitalizați au arătat că efectele separării de familie aprofundează suferința cu reflectare negativă asupra capacității lor de recuperare. Psihologii susțin faptul că prezența părinților (în special a mamei sau a persoanei care îngrijeşte copilul) îi asigură acestuia un echilibru psihoemoțional, factor important în calitatea vieții şi pentru parcursul recuperator.

Percepția pe care copilul o are despre propria familie este profund legată de factori culturali, etnici şi religioşi. Din aceste motive, prezența familiei alături de copil sau adolescent trebuie realizată cu multă pricepere şi deschidere, pentru că părintele reprezintă un factor liant între pacient şi echipa medicală (8) Dar, realizarea acestui obiectiv poate fi influențată puternic de credințele familiei. De exemplu, Bowmen şi Zinger au evidențiat faptul că membrii comunității chineze din Toronto respingeau directiva în avans motivând prin: ,gândurile negative atrag după ele consecințe negative“. (9)

\section{Perspectiva membrilor familiei}

Câteva cercetări conduse de Jabre et al au urmărit beneficiile asupra stării de bine psihologice a rudelor care au asistat la manevrele de resuscitare. Studiile au evaluat efectele pozitive pe termen scurt şi lung asupra stării psihologice a membrilor familiei şi a nivelului de stres post-traumatic asociat evenimentului critic la care au participat (10). Rezultatele prezentate în cercetarea din 2014 evidențiază consecințele pozitive ale asistării unui membru al familiei pe parcursul resuscitării asupra trăirii stării de doliu ulterioare decesului pacientului (grief, bereavement, mourning). Starea obişnuită consecutivă unui eveniment cu impact major asupra persoanei (deces, eveniment traumatizant etc.) nu este considerată o tulburare mentală. Spre deosebire de aceasta, starea de doliu patologică (complicată sau traumatizantă) apare în manualul de clasificare a bolilor mentale şi reprezintă premisa dezvoltării tulburărilor psihologice - stresul traumatic şi stresul de separare (11). Rezultatele cercetării au pus în evidență faptul că participarea membrilor familiei la CPR diminuează efectele psihologice negative pe termen lung, diminuând nivelul depresiei, anxietăţii şi a stresului post-traumatic, rudele trecând cu mai puține consecințe psihoemoționale peste evenimentul nefericit.

Aceste rezultate prezentate şi în alte studii sunt legate de dorința familiei de a avea un rol activ în procesul de luare a deciziilor pe parcursul resuscitării (12). Implicarea creează sentimentul că au participat activ şi au făcut tot ceea ce le-a stat în putință pentru a-şi salva copilul, adaptându-se astfel mai uşor la situația stresantă prin care au trecut şi acceptând consecințele ei. Pe de altă parte, în unele situații, sunt înlăturate chiar şi suspiciunile cu privire la eforturile de resuscitare făcute dincolo de uşile închise ale sălilor de reanimare, se construiesc aşteptări realiste în corelație cu starea pacientului pentru că rudele au avut posibilitatea să vadă pas cu pas evoluția sa din punct de vedere medical. În stări terminale se oferă posibilitatea ca ruda să îşi ia rămas-bun şi să fie alături de pacient până la sfârşitul vieții, ceea ce creează membrilor familiei sentimentul că 1-au îngrijit şi i-au fost alături până la sfârşit $(10,11)$.

În cazul copiilor aflați în stare critică, sentimentele de culpabilitate şi neputinţă ale familiei imprimă o dorință mai puternică de a participa la resuscitare, comparativ cu rudele care asistă adulți. Chiar şi în cazul manevrelor medicale mai simple, deşi nivelul de anxietate al mamelor este ridicat şi există suspiciunea că această stare este transmisă copiilor, s-a observat faptul că micii pacienți sunt mai colaborativi şi prezintă niveluri de anxietate mai mici comparativ cu cei care nu sunt asistaţi (13). Deşi îngrijorată de starea copilului şi conştientă de situaţia în care acesta se află, mama găseşte resurse şi unelte necesare pentru a scădea nivelul de distres al pacientului (ştie ce îi face plăcere, utilizează metoda potrivită de a-1 linişti, îl încurajează, proiectează situații în viitor cu impact pozitiv asupra copilului, practică metode de relaxare adecvate acestuia atingerea, cuvintele, muzica etc). Membrii familiei micilor pacienți preferă, în proporție de aproximativ $75 \%$, să participe la manevrele de resuscitare, comparativ cu rudele pacienților adulți, unde ratele de dezirabilitate sunt de aproximativ 55\% (14).

Psihologic, posibilitatea acordată părinților de a participa la manevrele medicale în situații dificile le instaurează sentimentul de redobândire a rolului parental, atât de afectat pe parcursul spitalizărilor, când responsabilitatea este preluată de către personalul medical. Cercetările cu privire la nivelul de distres al părinţilor care au copii bolnavi indica drept factor important alterarea modelului parental şi ideea că nu pot controla şi interveni pentru a-şi ajuta copiii (15).

Părinții, ca participanți activi ai echipei de intervenție au interferențe minore în proceduri; într-o evaluare comportamentală toți au oferit suport copiilor: $91 \%$ au vorbit, iar $73 \%$ i-au mângâiat sau sărutat (16). Foarte rar rudele participante obstrucțio- 
nează manevrele medicale. Distresul părinților după participarea la intervenții invazive şi dureroase asupra copiilor lor este durabil; a fost evaluat la 6 luni la mamele copiilor mici şi până la 2 ani în cazul mamelor cu nou-născuți aflați în stare de risc (17).

Chiar dacă efectele pozitive sunt evidențiate de multe studii, alte cercetări punctează şi aspectele negative ale asistării la manevrele medicale făcute pacienților în situații critice (18), menționându-se brutalitatea manevrelor de resuscitare, tratarea pacientului ca obiect, dezgolirea, lipsa de apărare şi de reacție, explorări şi tratamente invazive, bruscarea şi rapiditatea acțiunilor, poate să creeze rudelor care asistă o situație de distres psihoemoțional major.

\section{Perspectiva personalului medical}

Procentele medicilor care sunt de acord cu participarea membrilor din familie, apropiați pacientului, nu depăşesc 50\% (19).

În opinia asistentelor medicale, prezența membrilor familiei pe parcursul manevrelor de resuscitare ar fi nepotrivită invocându-se neplăcerea de a fi privite în timpul lucrului (47,6\%), dificultatea de a fi atenți la limbajul şi termenii utilizați pe parcursul intervenției, deoarece unele remarci pot fi interpretate greşit de către aparținătorii pacienților (75\%). În procent de 48,4\%, asistentele medicale nu au fost de acord cu prezența unui membru al familiei pe parcursul activității lor, iar $52,8 \%$ au declarat că nu au fost pregătite profesional de a se ocupa de membrii familiei, pentru a le oferi un suport psihologic şi emoțional (20). Alte rezultate evidențiază faptul că personalul medical este deranjat de nivelul de stres. Anxietatea echipei medicale care lucrează sub presiunea familiei, uneori obligați să continue manevrele de resuscitare la insistențele acesteia, este amplificată de teama de a nu fi acuzați cu privire la profesionalismul lor (21).

În studiile mai recente se remarcă aderarea mai puternică a personalului medical la ideea ca membrii familiei să participe la manevrele medicale, acceptarea beneficiilor de ordin psihologic pentru aparținători fiind recunoscute. Personalul medical conştientizează nevoia de pregătire specifică pentru a face față adecvat comportamentului familiei şi a dificultăților cauzate de prezența unei persoane implicate emoțional şi cu aşteptări mari şi trebuie să fie instruită să facă față atât situației în care se află pacientul, cât şi comportamentului anxios al părinţilor (22). Printre comportamentele dezirabile, pe care familiile pacienților aflați în situații critice le aşteaptă de la asistente, sunt: menținerea contactului vizual pe parcursul comunicării cu aceştia, a nu ocoli familia când cere informații suplimentare despre starea pacientului şi a răspunde prompt şi sincer cu privire la prognostic (23).

Diferențele cu privire la acceptarea familiei în momentele critice ale copilului au fost explicate prin particularități etice şi politica de sănătate implementată în diverse țări. De exemplu, interogarea asistentelor medicale din Suedia a evidenţiat reticențe în acceptarea familiei comparativ cu asistentele din UK. Este posibil ca țările cu un model de îngrijire mai paternalist să excludă participarea familiei la evenimentele critice, în timp ce țările care au adoptat un comportament de îngrijire holistic să fie mai receptive la integrarea rudelor în cadrul manevrelor de intervenție în situații de criză. Fără îndoială însă, orientarea către îngrijirea centrată pe familie (family-centered care) determină o abordare cu efecte pozitive atât asupra pacientului, cât şi asupra membrilor familiei.

Există diferențe între diversele categorii de personal medical privind nivelul de acceptare a prezenței familiei în situații critice, precum resuscitarea cardio-pulmonară. Medicii, asistentele medicale, personalul tehnic de îngrijire (critical care techs) sau preoții din spital sunt mai puțin deranjați de prezența familiei spre deosebire de tehnicienii care manipulează aparatele pacienților, personalul care asigură siguranța, farmacişti sau personalul de resuscitare (24).

Pentru a integra cu eficiență membrii familiei pe parcursul manevrelor medicale, personalul medical trebuie să fie instruit cu privire la: modalitatea de abordare a familiei, asistența lor pe parcursul desfăşurării momentelor critice, utilizarea abilităților de comunicare, furnizarea informațiilor cu privire la manevre şi prognostic precum şi consilierea rudelor în cazul unui final nefericit.

\section{Perspectiva managementului spitalelor}

Multe dintre departamentele de intervenție de urgentă din cadrul spitalelor universitare din SUA şi Europa de Vest dispun de protocoale şi personal specializat pentru a integra rudele pacienților să asiste la CPR. Câteva studii au identificat faptul că gradul de satisfacție al familiei depinde şi de permisivitatea spitalului, de condițiile suplimentare create pentru facilitarea vizitelor, organizarea de întâlniri destinate membrilor familiei, pregătirea personalului mediu pentru a comunica cu familia şi adoptarea unui model centrat pe familie în cazul pacienților aflați în stare gravă (25). Personalul medical, deşi deschis la a permite familiei să asiste la manevrele medicale, rămâne reticent, ceea ce determină conducerea unităţii să ocolească impunerea unor măsuri. 
Cercetările care au urmărit opinia personalului de conducere al instituțiilor medicale au identificat faptul că respondenții sunt conştienți că membrii familiei pot tolera din punct de vedere emoțional situațiile de CPR (59\%), nu interferează cu manevrele de îngrijire a pacienților şi că echipa medicală nu este afectată de prezența familiei (88\%). De asemenea, facilitatorul familiei, special instruit pentru a comunica cu familia şi a-i acorda consiliere în situațiile de CPR, este de obicei o asistentă medicală care participă la toate cazurile speciale (70\%) (26).

Impunerea protocoalelor care ghidează integrarea familiei şi participarea acesteia la procesul luării deciziilor a fost rezultatul identificării consecințelor pozitive pentru managementul spitalelor: creşterea satisfacţiei rudelor cu privire la serviciile oferite, reducerea numărului de conflicte între familie şi personalul medical, diminuarea expectanțelor nerealiste ale rudelor, îmbunătățirea relaţiei între personalul medical şi membrii familiei şi reducerea conflictelor litigioase. De asemenea, prezența familiei ajută ca părinții să înțeleagă şi să accepte cu mai multă uşurință condiția medicală a copiilor (27).

\section{CONCLUZII}

Centrarea pe îngrijirea pacientului, dar şi a familiei, pe parcursul tratamentului, spitalizărilor, intervențiilor medicale sau în situațiile critice este din ce în ce mai răspândită şi implementată în spitale, clinici şi centre de îngrijire. Protocoalele de intervenție şi pregătirea personalului medical pentru a comunica cât mai eficient cu membrii familiei ghidează asimilarea acestora în echipa de intervenție şi dă posibilitatea rudelor de a participa în mod activ şi uneori de a decide cu privire la îngrijirea pacientului. Acceptarea membrilor familiei pe parcursul manevrelor medicale aduce beneficii în ceea ce priveşte dezvoltarea ulterioară a problemelor psihologice, precum stresul post-traumatic, depresia sau anxietatea. Disponibilitatea personalului medical de a accepta rudele în timpul resuscitării cardiopulmonare depinde de modelul de intervenție obişnuit în țara respectivă şi este influențat de factori diverşi precum cultura, pregătirea profesională a persoanelor de suport sau politicile de sănătate. Totuşi, participarea familiei pe parcursul manevrelor medicale rămâne o recomandare şi nu o obligație. 